\title{
SENSORY ACCEPTANCE AND PHYSICO-CHEMICAL COMPOSITION OF MIXED MINAS FRESCAL CHEESE
}

\author{
ACEITAÇÃO SENSORIAL E COMPOSIÇÃO FÍSICO-QUÍMICA DE QUEIJO MINAS \\ FRESCAL MISTO
}

\author{
Bruna Samara dos Santos REKOWSKY; Géssica Cordeiro de ARAÚJO² \\ Nelson de Carvalho DELFINO ${ }^{3}$; Marion Pereira da COSTA ${ }^{4}$; Thadeu Mariniello SILVA ${ }^{5}$ \\ 1. Universidade Federal da Bahia- UFBA, Programa de Pós-Graduação em Ciência Animal nos Trópicos - PPGCAT. \\ bruna.rekowsky@hotmail.com; 2. Universidade Federal da Bahia - UFBA, Escola de Medicina Veterinária e Zootecnia - EMEVZ; \\ 3. Programa de Pós-Graduação em Zootecnia - PPGZ, UFBA; 4. UFBA, Laboratório de Inspeção e Tecnologia de Leites e \\ Derivados, Departamento de Medicina Veterinária Preventiva e Produção Animal; 5. UFBA, Departamento de Medicina Veterinária \\ Preventiva e Produção Animal, Salvador, Brasil.
}

\begin{abstract}
Buffalo milk presents higher proteins and lipids concentration than cow milk, which provides a better yield in cheese-making production and products with considerable sensory approval. However, buffalo milk is not regularly available throughout the year due to different handling conditions. Thus, to guarantee the supply of buffalo milk dairy products during the year, the addition of bovine milk is an alternative. Therefore, this study aimed to test the effect of a buffalo and bovine milk mixture for the Minas Frescal cheese elaboration by physico-chemical, sensory analysis and obtaining yield. The raw material was analysed for the parameters of acidity, density, fat, total solids and solid-not-fat. There were 3 Minas Frescal cheeses elaborated from 3 formulations: $100 \%$ buffalo milk, $100 \%$ bovine milk and the mixture of $50 \%$ of each milk. The cheeses were submitted to the Gravimetric and Gerber methods to obtain values of moisture and fat, as well as to obtain, indirectly, fat in dry matter. For bovine and buffalo milk, the parameters evaluated (acidity, density, fat, total solids and solids-not-fat) complied with Brazilian legislation and parameters described in the literature. For the bovine, mixed and buffalo fresh cheeses, values were obtained, respectively, for moisture (74.04, 60.93 and 63.61), fat in dry matter (44.35, 42.23 and 46.03) and cheese yield (27, 20.8 and 24.2), indicating a higher yield for the bovine Minas Frescal cheese and higher fat content for the buffalo cheese. The overall acceptance of the mixed Minas Frescal cheese was significantly superior to the bovine and buffalo cheese. The parameters of colour, appearance, texture, flavour and overall acceptance were above 8 points in the hedonic scale ('moderately liked' to 'extremely liked'), and the aroma attribute scored was above 7 ('I enjoyed regularly' to 'moderately liked'). Therefore, the elaboration of Minas Frescal cheese from the mixture of 2 matrices (buffalo and bovine milk) demonstrated technological viability with the potential to meet the demands of the consumer market.
\end{abstract}

KEYWORDS: Bovine milk. Buffalo milk. Dairy product. Fresh cheese.

\section{INTRODUCTION}

Cheese consumption influences human health as it is a food rich in lipids, proteins, minerals and vitamins, and the Minas Frescal cheese is relevant in Brazil for being one of the most consumed by the population in the country (MATERA et al., 2018). Besides that, this type of cheese has easy elaboration and high yield, which allows a fast investment at a lower cost (COSTA et al., 2013). Bovine milk presents a consolidated and lower-priced production (IBGE, 2017), which makes it the most generally used raw material for Minas Frescal cheese production.

Compared to bovine milk, buffalo milk has a higher percentage of all components (fat, protein, yield), and it is particularly important to provide a higher cheese yield, resulting in improved cheesemaking potential (ZICARELLI, 2004). Between 1980 and 2011, bovine milk production increased by $48 \%$, while buffalo milk production increased by 238\% (RICCI; DOMINGUES, 2012), and according to Bernardes (2018), about $85 \%$ of the production of buffalo milk is destined for the elaboration of dairy products.

However, buffalo milk is not regularly available throughout the year because the concentration of calving and consequent lactation period occurs in periods of low pasture supply (SIMÕES et al., 2013), bringing losses to dairy production of this species. Due to the seasonality of buffalo milk production, mixing it with bovine milk 
is an alternative to guarantee the offer of buffalo milk dairy products throughout the year.

Few studies have evaluated the potential of dairy products made from the mixture of buffalo and cow's milk, associating the physico-chemical and yield data with the sensory acceptance of these mixed cheeses (CARDOSO et al., 2019; SIMÕES et al., 2013). Therefore, this study aimed to evaluate the potential of the mixture of milk matrices (buffalo and bovine) for technological processing innovation of Minas Frescal cheese based on physico-chemical data, yield performance and sensorial acceptance of the new product elaborated.

\section{MATERIAL AND METHODS}

\section{Obtaining the raw material}

There were 10 litres obtained of each milk (buffalo and bovine milk) from the Fazenda Experimental de Entre Rios of the Universidade Federal da Bahia (UFBA). The raw material was obtained by mechanical milking and cooled to $4^{\circ} \mathrm{C}$. For transportation, the milk was packed in bottles of 05 litres kept in a thermal box, and, at the laboratory, it was kept in refrigeration until the analysis of the samples and preparation of the cheeses. Both milk samples were evaluated for acidity, density, fat, total solids and solids-not-fat according to the AOAC (2012). The Minas Frescal cheeses were prepared at the Laboratorio de Inspeçao e Tecnologia de Leite e Derivados (LaITLacteos) located at the Escola de Medicina Veterinária e Zootecnia (UFBA).

\section{Elaboration of the Minas Frescal cheeses and physicochemical analysis}

There were three cheese treatments performed: (CBO) 100\% bovine milk, (CBB) Mixture $50 \%$ bovine milk $+50 \%$ buffalo milk and (CBU) 100\% buffalo milk. The cheese manufacturing procedures followed the steps described by Verruck et al. (2015), using, as ingredients, calcium chloride $(0.02 \%)$, cultures provided by natural skim yogurt (1.8\%; Nestlé), sodium chloride $(0.8 \%$; Sal Lebre) and liquid coagulant (CHY-MAX $\left.{ }^{\circledR}\right)$.

The milk samples were pasteurized $\left(65^{\circ} \mathrm{C}\right.$ for 30 minutes) and then cooled to $35^{\circ} \mathrm{C}$. After that, the lactic culture was added, followed by the addition of calcium chloride and liquid coagulant according to the manufacturer's instructions. The sodium chloride was added during the agitation step to incorporate into the mass. Plastic moulds with a cylindrical shape and with holes in the bottom, which allowed the serum to be drained, were used for placing the cheese mass that was left in the oven for 30 minutes. After the production, the cheeses were kept refrigerated at $4 \pm 1^{\circ} \mathrm{C}$ for approximately 24 hours until the physico-chemical and sensorial analysis.

Following the classification requirements for Minas Frescal cheese (BRASIL, 2004), samples were collected for physico-chemical characterisation, including moisture by the gravimetric method and fat by the Gerber butyrometer method according to the AOAC (2012). The fat was calculated in dry matter $(\mathrm{g} / 100 \mathrm{~g})$, and the cheese yield (CY\%) was calculated according to El-Gawad and Ahmed (2011).

\section{Sensory evaluation of cheeses}

The test sessions were performed in 1 day. There were 100 participants (70 women, 30 men), ranging from 19 to 58 years-old, recruited at the Universidade Federal da Bahia. The test was performed in a laboratory under controlled conditions of light, temperature and sound. The exclusion criterion was people with allergies or intolerance to dairy products. The participants evaluated colour appearance, aroma, flavour, texture and overall acceptability of each sample based on a 9-point hedonic scale $(9=$ liked extremely; 5= neither liked nor disliked, and $1=$ disliked extremely).

\section{Statistical analysis}

All data were submitted to analysis of variance, followed by the Tukey test when significant (Except the physico-chemical analysis of milk), using the PROC GLM of SAS 9.1 program (SAS Inst. Inc., Cary, NC). Significance was declared at P-values $<0.05$.

\section{RESULTS AND DISCUSSION}

\section{Physico-chemical characterisation of the raw material}

The fat content and total solids of buffalo milk were slightly higher $(\mathrm{P}<0.05)$ than those of bovine milk (Table 1) but there were no significant differences between the other parameters evaluated $(\mathrm{P}>0.05)$. The buffering capacity (capacity of acidification) is higher in buffalo milk than in cow's milk (AHMAD et al., 2008), which may justify the difference of acidity between the 2 matrices, and, nevertheless, the results of density and acidity are in accordance with legislation (BRASIL, 2018). 
Table 1. Physico-chemical analysis of the raw material for Minas Frescal cheeses preparation.

\begin{tabular}{lccccc}
\hline \multirow{2}{*}{\multicolumn{1}{c}{ Parameters }} & \multicolumn{2}{c}{ Species } & P-Value & Reference $^{\mathbf{1}}$ & Reference $^{3}$ \\
\cline { 2 - 5 } & Bovine & Buffalo & & & \\
\hline Total Solids (\%) & $13.31 \pm 0.54$ & $14.54 \pm 0.46$ & 0.040 & Min. 11.4 & 12.60 to 15.90 \\
Solids-not-fat (\%) & $9.54 \pm 0.09$ & $9.97 \pm 0.45$ & 0.184 & Min. 8.4 & 8.28 to 9.40 \\
Fat (\%) & $3.77 \pm 0.45$ & $4.57 \pm 0.21$ & 0.049 & Min. 3.0 & 4.0 to 6.5 \\
Density (g/mL) & $1.034 \pm 0.0$ & $1.035 \pm 0.002$ & 0.374 & 1.028 to 1.034 & - \\
Acidity (D & $18.0 \pm 1.73$ & $16.0 \pm 0.0$ & 0.116 & 14 to 18 & 11.0 to 18.0
\end{tabular}

${ }^{1}$ Different means on the same line differ by significance at P-value $<0.05$.

${ }^{2}$ According to Brazilian regulations for bovine milk (BRASIL, 2018).

${ }^{3}$ Values reported in the literature buffalo milk (AHMAD et al., 2013; KANWAL; AHMED; MIRZA, 2004; MURTAZA et al., 2013).

The observed data corroborate the findings of other authors that indicate that total solids and total solids decreased, respectively, $14.04 \%$ and $8.79 \%$ for buffaloes and $13.73 \%$ and $9.17 \%$ for bovines (KANWAL; AHMED; MIRZA, 2004). Several studies present data about the buffalo milk composition, such as protein (3.81 to 4.8), fat content ( 4.0 to 8.54 ), lactose ( 4.68 to 4.99$)$, minerals ( 0.79 to 0.88$)$ and total solids (12.60 to 18.96$)$, and these components are strongly connected to the formation of the curd (CIPOLAT-GOTET et al., 2015; MELO et al., 2018; HAN et al., 2007; MURTAZA et al., 2013;).

\section{Cheese yield and physico-chemical} characterisation of cheeses

The cheese yield (CY\%) of the bovine Minas Frescal cheese was higher than that of the other elaborated varieties and was less in the mixed cheese production (Table 2). This high yield for the bovine cheese can be explained by the higher percentage of moisture $(\mathrm{P}<0.05)$ when compared with other treatments. According to the legislation for Minas Frescal cheese, which was considered a 'very high humidity' cheese and must have values above $55 \%$ for moisture (BRASIL, 2004).

Table 2. Physicochemical analysis of Minas Frescal cheese made with bovine, buffalo and mixed milk.

\begin{tabular}{lcccc}
\hline \multirow{2}{*}{ Parameters } & \multicolumn{3}{c}{ Physico-chemical analysis } & P- Value \\
\cline { 2 - 5 } & CBO & CBB & CBU & - \\
\hline Cheese yield (\%) & 27.00 & 20.80 & 24.20 & 0.0013 \\
Moisture (\%) & $73.0^{\mathrm{a}} \pm 1.20$ & $60.0^{\mathrm{b}} \pm 1.5$ & $64.0^{\mathrm{b}} \pm 1.0$ & $<0.0001$ \\
Dry matter (\%) & $27.1^{\mathrm{c}} \pm 1.20$ & $39.1^{\mathrm{a}} \pm 1.59$ & $35.5^{\mathrm{b}} \pm 0,84$ & 0.0004 \\
Fat (\%) & $11.5^{\mathrm{b}} \pm 0.50$ & $15.0^{\mathrm{a}} \pm 1.04$ & $16.8^{\mathrm{a}} \pm 0.52$ & 0.0147 \\
Fat in dry matter (\%) & $42.2^{\mathrm{ab}} \pm 1.93$ & $40.2^{\mathrm{b}} \pm 2.63$ & $46.1^{\mathrm{a}} \pm 1.05$ & \\
\hline
\end{tabular}

$\mathrm{CBO}=$ cheese made from $100 \%$ bovine milk; $\mathrm{CBB}=$ Cheese made from $50 \%$ bovine milk and $50 \%$ buffalo milk and CBU $=$ cheese made from $100 \%$ buffalo milk.

${ }^{2}$ Different means on the same line differ by Tukey's test with $\mathrm{P}<0.05$.

Wide variation in the moisture content of bovine Minas Frescal (50.07 to 74.49) was also observed in artisanal and industrialised cheeses in Brazil (DIAS et al., 2016; MAGENIS et al., 2014). The syneresis (loss of whey) depends on factors such as the amount of protein and calcium and $\mathrm{pH}$ reduction and directly influences the moisture content of the cheese (PAULA; CARVALHO; FURTADO, 2009). Considering that buffalo milk has higher amounts of protein and calcium (HUMA et al., 2018), associated with the fact that casein micelles are larger in this milk matrix, it tends to cause faster and more efficient coagulation when compared to cow's milk, with less moisture retention (KHEDKAR; KALYANKAR; DEOSARKAR, 2016). Thus, cow's milk would probably need more time to complete the syneresis process.

Despite the lower amount of fat $(\mathrm{P}<0.05)$ in CBO cheese, the fat/fat in the dry matter ratio for this treatment is favoured due to the higher moisture content and, consequently, lower dry matter content. The amount of fat in dry matter (FDM) was 
observed in greater quantities for CBU cheese ( $\mathrm{P}$ $<0.05$ ) when compared with $\mathrm{CBB}$, but there was not a significant difference $(\mathrm{P}>0.05)$ when compared with the CBO treatment. The addition of bovine milk resulted in a decrease in the percentage of mixed cheese FDM in comparison to buffalo cheese (SIMÕES et al., 2013), and in accordance with the legislation, both $\mathrm{CBO}$ and $\mathrm{CBB}$ were considered semi-fat cheeses (FDM between 25.0 to $44.9 \%$ ) while the CBU treatment was classified as a fat cheese (BRASIL, 1996). In Minas Frescal cheeses marketed in the country, the fat content $(8.08 \%$ to $25.57 \%)$ and FDM (23.12\% to $52.47 \%)$ show great variation (MAGENIS et al., 2014); therefore, there is an absence of standardisation of the raw material and technological processing of this type of dairy derivative, which becomes a challenge concerning quality control (SOUZA et al., 2019).

The yield of the bovine Minas Frescal cheese was 3.7 litres of milk for each $1 \mathrm{~kg}$ of the product, while the yield of the fresh buffalo cheese was 4.1 litres of milk per kilo of cheese produced, corroborating Moraes et al. (2006), who needed 4.7 litres of buffalo milk per kilo of Minas Frescal cheese. The mixed Minas Frescal CY\% was $4.8 \mathrm{~kg}$ of milk/ $\mathrm{kg}$ of product, and, although it was inferior to the other treatments, it is still similar to the other Minas Frescal cheese from buffalo as well as from bovine milk (ANTUNES et al., 2017; YUNES; BENEDET, 2000). These results demonstrate the need for further studies about the effect of a mixture of milk of different species on fresh cheese yield.

\section{Sensory analysis}

According to the average score obtained through the hedonic scale (1 to 9), it was observed that most of the parameters of Minas Frescal mixed cheese presented above 8.0 points, with a rating of 'liked moderately' to 'liked extremely', which makes their approval evident, both for the overall acceptance and for the other evaluated attributes. In addition, the score obtained by the mixed cheese was higher or equal in all attributes when compared to fresh cheeses from bovine and buffalo milks (Table 3).

Table 3. Sensory analysis of Minas Frescal cheeses.

\begin{tabular}{|c|c|c|c|c|}
\hline \multirow{2}{*}{ Parameters $^{1}$} & \multicolumn{3}{|c|}{ Minas Frescal Cheese } & \multirow{2}{*}{ P-Value } \\
\hline & $\mathrm{CBO}$ & CBB & $\mathrm{CBU}$ & \\
\hline Colour & $7.97^{\mathrm{b}}$ & $8.33^{\mathrm{a}}$ & $8.16^{\mathrm{ab}}$ & $<0.001$ \\
\hline Appearance & $7.42^{\mathrm{b}}$ & $8.35^{\mathrm{a}}$ & $8.05^{\mathrm{a}}$ & $<0.001$ \\
\hline Aroma & $7.39^{\mathrm{b}}$ & $7.85^{\mathrm{a}}$ & $7.68^{\mathrm{ab}}$ & 0.010 \\
\hline Texture & $7.06^{\mathrm{b}}$ & $8.23^{\mathrm{a}}$ & $8.13^{\mathrm{a}}$ & $<0.001$ \\
\hline Flavour & $7.85^{\mathrm{ab}}$ & $8.06^{\mathrm{a}}$ & $7.45^{\mathrm{b}}$ & 0.003 \\
\hline Overall acceptance & $7.50^{\mathrm{b}}$ & $8.11^{\mathrm{a}}$ & $7.59^{\mathrm{b}}$ & $<0.001$ \\
\hline
\end{tabular}

$\mathrm{CBO}=$ cheese made from $100 \%$ bovine milk; $\mathrm{CBB}=$ Cheese made from $50 \%$ bovine milk and $50 \%$ buffalo milk and $\mathrm{CBU}=$ cheese made from $100 \%$ buffalo milk.

${ }^{1}$ Values punctuated in hedonic scale from 1 to 9.

Different means in the same line differ among themselves by the Tukey test with $\mathrm{P}<0.05$.

The colour evaluation of CBU did not vary significantly $(\mathrm{P}>0.05)$ when compared to the CBB treatment but was superior to that of the bovine fresh cheese $(\mathrm{P}<0.05)$. According to Simões et al. (2013), the colour and appearance of Marajó cream cheese varied due to the addition of bovine milk, so the brightness and green colour of the buffalo milk was reduced, and yellow colouration was noticed with the addition of bovine milk. Therefore, it can be assumed that the yellowish colouration of bovine milk was a positive factor compared to the visual evaluation of the taster, causing a better score for the mixed cheese in this question and it. This fact was also observed by Cardoso et al. (2019) who presented superior colour scores for mixed soft cheese in comparison to those made with only bovine or buffalo milk.

The interaction of volatile components of fatty acids influences the flavour and aroma of the Minas Frescal cheese, conferring a mild and pleasant flavour and low aromatic thresholds (NOGUEIRA; LUBACHEVSKY; RANKIN, 2005). Although CBU presented higher fat in dry matter, the buffering capacity (slow acidification), lower retention of moisture and increased time for lipolysis and proteolyzes can negatively influence the sensory profile of buffalo dairy (KHEDKAR; KALYANKAR; DEOSARKAR, 2016). So, it is possible to perceive that the flavour attribute was enhanced by the presence of bovine milk once CBO received higher values when compared with $\mathrm{CBU}$ 
$(\mathrm{P}<0.05)$. On the other hand, buffalo milk contributed to improve the sensory texture since CBU cheeses received higher scores $(\mathrm{P}<0.05)$ than the $\mathrm{CBO}$.

The overall acceptance of the CBB cheese was significantly higher $(\mathrm{P}<0.05)$ than that of both bovine and buffalo Minas Frescal cheeses. The results of the sensorial analysis indicate that the CBB treatment obtained the highest average score for all the evaluated attributes and presented a satisfactory cheese yield. So, it is possible to infer that dairy products developed from the mixture milk of different species may eventually outperform the sensory qualities of milk matrix products of a single species.

\section{CONCLUSION}

The Minas Frescal cheese was considered a 'very high humidity cheese' $(60.0 \%)$ and a 'semifat' $(40.2 \%)$ cheese, conforming to the legislation. All parameters, except for aroma, were rated as 'liked moderately' to 'liked extremely', with scores above 8.0. Because of the sensory approval obtained by the Minas Frescal cheese elaborated from the mixture of buffalo and bovine milks, added to its physico-chemical properties and satisfactory production yield, we can conclude that mixed Minas Frescal cheese presents technological potential for the dairy industry and can play a role in the valorisation of the production chain of buffalo dairy in the country.

\section{ACKNOWLEDGEMENTS}

The authors thanks the Fazenda Experimental de Entre Rios of the Universidade Federal da Bahia (UFBA) for providing the bovine and buffalo milks and thanks the Conselho Nacional de Desenvolvimento Científico e Tecnológico (process no. 405728/2018-2 and 402430/2018-2, CNPq, Brazil) and Coordenação de Aperfeiçoamento de Pessoal de Nível Superior Brasil (CAPES) for their financial suport.

RESUMO: O leite de búfala possui maior porcentagem de todos os componentes tornando-o uma matéria-prima adequada com potencial para fornecer um maior rendimento e qualidade nutricional na produção de queijo. No entanto, o leite de búfalo não está disponível regularmente ao longo do ano devido a diferentes condições de manejo. Assim, para garantir a oferta de produtos lácteos com leite de búfala independentemente da época, a adição de leite bovino pode ser vista como uma alternativa. Logo, este trabalho teve como objetivo testar o efeito da mistura do leite de búfalo e bovino na elaboração do queijo Minas Frescal por meio de análises físico-químicas e sensoriais e obtenção do rendimento economico. A matéria-prima foi analisada quanto aos parâmetros: acidez titulável, densidade, gordura, sólidos totais e sólidos totais desengordurados. Três variedades de queijo Minas Frescal foram elaboradas a partir de três formulações: 100\% de leite de búfala, $100 \%$ de leite bovino e da mistura de 50\% de cada leite. Os queijos foram submetidos aos métodos Gavimetric e Gerber para obtenção de umidade e gordura, bem como, indiretamente, para obtenção de matéria gorda no extrato seco. Para o leite bovino e de búfala, os parâmetros avaliados (acidez titulável, densidade, gordura, sólidos totais e sólidos totais desengordurados) estavam de acordo com a legislação brasileira e parâmetros descritos na literatura. Para os queijos bovino, misto e de búfala, foram obtidos, respectivamente, para: umidade $(74,04 ; 60,93$ e 63,61$)$, gordura na matéria seca $(44,35 ; 42,23$ e 46,03) e rendimento econômico $(27,20,8$ e 24,2) indicando maior rendimento o queijo Minas Frescal bovino e maior teor de gordura para o queijo búfalo. A aceitação global do queijo Minas Frescal misto foi significativamente superior ao do queijo bovino e bubalino. Os parâmetros de cor, aparência, textura, sabor e aceitabilidade global foram acima de 8 pontos (entre "gostei moderadamente" e "extremamente gostei") e o atributo aroma obteve pontuação acima de 7 ("gostei regularmente" para "gostei moderadamente"). Portanto, a elaboração do queijo Minas Frescal da mistura de leite bovino ao búfalo demonstrou potencial para atender as demandas do mercado consumidor.

PALAVRAS-CHAVE: Derivado lácteo. Leite de vaca. Leite de búfala. Queijo fresco.

\section{REFERENCES}

AHMAD, S.; ANJUM, F. M.; HUMA, N.; SAMEEN, A.; ZAHOOR, T. Composition and physico-chemical characteristics of buffalo milk with particular emphasis on lipids, proteins, minerals, enzymes and vitamins. $\mathbf{J}$ Anim Plant Sci, v. 23, n. Suppl 1, p. 62-74, 2013. 
AHMAD, S.; GAUCHER, I.; ROUSSEAU, F.; BEAUCHER, E.; PIOT, M., GRONGNET, J. F.; GAUCHERON, F. Effects of acidification on physico-chemical characteristics of buffalo milk: A comparison with cow's milk. Food Chemistry, v. 106, n. 1, p. 11-17, 2008.

https://doi.org/10.1016/j.foodchem.2007.04.021

ANTUNES, C. R.; JUNIOR, V. R. R.; CALDEIRA, L. A.; SOUSA, C. F.; RIGUEIRA, J. P. S.; DE SOUZA, G. R.; ALVES, W. S.; SOARES, C.; DE MENEZES, J. C. Efeito da casca de banana na dieta de vacas em lactação sobre as características do leite e do queijo Minas frescal. Revista Brasileira de Ciência Veterinária, v. 24, n. 4, 2017. https://doi.org/10.4322/rbcv.2017.036

AOAC International. 2012. Official Methods of Analysis. 19th ed. AOAC Int., Arlington, VA.

BERNARDES, Otavio. Estimativa do rebanho bubalino brasileiro em 2016 e seu impacto econômico.

Researchgate (www.researchgate.net/publication/323268766), 2018.

BRASIL. Instrução Normativa $\mathrm{n}^{\circ} 76$ - Regulamento técnico de identidade e qualidade de leite cru refrigerado, leite pasteurizado e leite pasteurizado tipo A. Diário Oficial da União, Brasília, 2018.

BRASIL. Instrução Normativa $n^{\circ} 04$ - Regulamento técnico para fixação de identidade e qualidade do queijo Minas Frescal. Diário Oficial da União, Brasília, 2004.

BRASIL. Portaria $n^{\circ} 146$ - Regulamento técnico de identidade e qualidade de queijos. Diário Oficial da União, Brasília, 1996.

CARDOSO, G. V. F.; OLIVEIRA, A. C. S.; SILVA, J. B.; DA SILVA, A. S.; ARAUJO, W. S. C.; LIMA NUNES, E. S. C.; ROOS, T. B.; MORAES, C. M. Evaluation of the experimental fraud of buffalo cheese by sensory analysis and physico-chemical parameters. Buffalo Bulletin, v. 38, n. 3, p. 521-529, 2019.

CIPOLAT-GOTET, C.; BITTANTE, G.; CECCHINATO, A. Phenotypic analysis of cheese yields and nutrient recoveries in the curd of buffalo milk, as measured with an individual model cheese-manufacturing process. Journal of Dairy Science, v. 98, n. 1, p. 633-645, 2015. https://doi.org/10.3168/jds.2014-8308

COSTA, M. P.; DA SILVA, H. L. A.; BALTHAZAR, C. F.; FRANCO, R. M.; CORTEZ, M. A. S. Economic performance and sensory analysis of probiotic "Minas Frescal" cheese produced using bovine and caprine milk. Enciclopédia Biosfera, v. 17, p. 2306-2314, 2013.

PAULA, J. C. J.; CARVALHO, A. F.; FURTADO, M. M. Princípios básicos de fabricação de queijo: do histórico à salga. Revista do Instituto de Laticínios Cândido Tostes, v. 64, n. 367, p. 19-25, 2009.

SOUZA, H. F.; PEREIRA, G. S. L.; GUIMARÃES, F.; NEVES, L. F.; SOARES, S. B.; DE CARVALHO, B. M. A.; BRANDI, I. V. Características físico-químicas do queijo Minas Frescal comercializados em feiras livres da cidade de Montes Claros, Minas Gerais. Caderno de Ciências Agrárias, v. 11, p. 1-5, 2019.

https://doi.org/10.35699/2447-6218.2019.3055

DIAS, B. F.; FERREIRA, S. M.; CARVALHO, V. S.; SOARES, D. S. B. Qualidade microbiológica e físicoquímica de queijo minas frescal artesanal e industrial. Journal of Neotropical Agriculture, v. 3, n. 3, p. 57-64, 2016. https://doi.org/10.32404/rean.v3i3.1211

EL-GAWAD, M. A. A.; AHMED, N. S. Cheese yield as affected by some parameters review. Acta Scientiarum Polonorum Technologia Alimentaria, v. 10, n. 2, p. 131-153, 2011.

HAN, B. Z.; MENG, Y.; LI, M.; YANG, Y. X.; REN, F. Z.; ZENG, Q. K.; NOUT, M. R. A survey on the microbiological and chemical composition of buffalo milk in China. Food Control, v. 18, n. 6, p. 742-746, 2007. https://doi.org/10.1016/j.foodcont.2006.03.011 
HUMA, N.; GHAFFAR, F.; RAFIQ, S.; PASHA, I.; SAMEEN, A.; HAYAT, I.; HUSSAIN, I. Characterization of milk proteins from different animal species through Gel electrophoresis. Pak J Zool, v. 50, p. 1983-1986, 2018. https://doi.org/10.17582/journal.pjz/2018.50.5.sc6

IBGE, Instituto Brasileiro de Geografia e Estatística. Censo Agropecuário, 2017.

KANWAL, R.; AHMED, T.; MIRZA, B. Comparative analysis of quality of milk collected from buffalo, cow, goat and sheep of Rawalpindi/Islamabad region in Pakistan. Asian Journal of Plant Sciences, v. 3, n. 3, p. 300-305, 2004. https://doi.org/10.3923/ajps.2004.300.305

KHEDKAR, C.; KALYANKAR, S.; DEOSARKAR, S. Buffalo milk. Encyclopedia of Food and Health, v. 93, p. 522-528, 2016. https://doi.org/10.1016/B978-0-12-384947-2.00093-3

MAGENIS, R. B.; PRUDÊNCIO, E. S.; FRITZEN-FREIRE, C. B.; STEPHAN, M. P.; DO EGITO, A. S.; DAGUER, H. Rheological, physicochemical and authenticity assessment of Minas Frescal cheese. Food Control, v. 45, p. 22-28, 2014. https://doi.org/10.1016/j.foodcont.2014.04.012

MATERA, J.; LUNA, A. S.; BATISTA, D. B.; PIMENTEL, T. C.; MORAES, J.; KAMIMURA, B. A.; FERREIRA, M. V. S.; SILVA, H. L. A.; MATHIAS, S. P.; ESMERINO, E. A.; FREITAS, M. Q.; RAICES, R. S. L.; QUITÉRIO, S. L.; SANT'ANA, A. S.; SILVA, M.C.; CRUZ, A. G. Brazilian cheeses: A survey covering physicochemical characteristics, mineral content, fatty acid profile and volatile compounds. Food Research International, v. 108, p. 18-26, 2018. https://doi.org/10.1016/j.foodres.2018.03.014

MELO, W. D. O.; MONTEIRO, B. M.; CHAVES, L. C. D. S.; SANTOS, E. R. D.; SOUZA, D. C. D.; AMORIM, B. S. D.; JUNIOR, S. P. F.; FILHO, J.D.R.; FATURI, C.; VIANA, R. B. Ultrasound spectroscopy as an alternative method to measure the physical-chemical constituents of buffalo milk. Ciência Rural, v. 48, n. 2, 2018. https://doi.org/10.1590/0103-8478cr20170447

MORAES, M.; VANZELER, M.; LOURENÇO JUNIOR, J. B.; VIEIRA, L.; MÜLLER, R. Caracterização do queijo minas frescal e da matéria-prima elaborado a partir do leite de búfala. In: Embrapa Amazônia Oriental-Resumo em anais de congresso (ALICE). In: CONGRESSO BRASILEIRO DE QUÍMICA, 46., 2006, Salvador. [Anais]. Rio de Janeiro: ABQ, 2006., 2006.

MURTAZA, M. A.; REHMAN, S. U.; ANJUM, F. M.; HUMA, N. Descriptive sensory profile of cow and buffalo milk Cheddar cheese prepared using indigenous cultures. Journal of Dairy Science, v. 96, n. 3, p. 1380-1386, 2013. https://doi.org/10.3168/jds.2012-5992

NOGUEIRA, M. C. L.; LUBACHEVSKY, G.; RANKIN, S. A. A study of the volatile composition of Minas cheese. LWT-Food Science and Technology, v. 38, n. 5, p. 555-563, 2005.

https://doi.org/10.1016/j.lwt.2004.07.019

RICCI, G. D.; DOMINGUES, P. F. O leite de búfala. Revista de Educação Continuada em Medicina Veterinária e Zootecnia do CRMV-SP, v. 10, n. 1, p. 14-19, 2012. https://doi.org/10.36440/recmvz.v10i1.255

SIMÕES, M. G.; DOMINGUES, A. F. N.; MACIEL, L. P.; RABELO, J. G.; OLIVEIRA, E. B.; FERREIRA, C. D. L. Efeito da adição de leite bovino ao leite de búfala nas diferentes características do queijo artesanal do Marajó, tipo creme. Embrapa Amazônia Oriental-Artigo em periódico indexado (ALICE), 2013.

VERRUCK, S.; PRUDÊNCIO, E. S.; VIEIRA, C. R. W.; AMANTE, E. R.; AMBONI, R. D. D. M. C. The buffalo Minas Frescal cheese as a protective matrix of Bifidobacterium BB-12 under in vitro simulated gastrointestinal conditions. LWT-Food Science and Technology, v. 63, n. 2, p. 1179-1183, 2015.

YUNES, V. M.; BENEDET, H. D. Desenvolvimento experimental de queijo fresco de leite da espécie bubalina. Food Science and Technology, v. 20, n. 3, p. 285-290, 2000. https://doi.org/10.1590/S010120612000000300002

ZICARELLI, L. Buffalo milk: its properties, dairy yield and mozzarella production. Veterinary Research ommunications, v. 28, p. 127, 2004. https://doi.org/10.1023/B:VERC.0000045390.81982.4d 
